\title{
Seasonal Abundance of Culicoides at Yongsan US Army Garrison (USAG) and Camp Humphreys USAG, Republic of Korea, 2010-2013 and 2014-2017
}

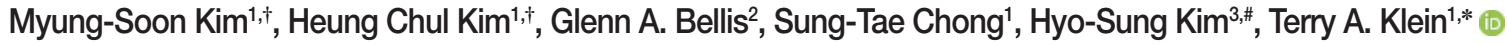 \\ 'Force Health Protection and Preventive Medicine, Medical Department Activity-Korea/65th Medical Brigade, Unit 15281, APO AP 96271-5281, \\ USA; ${ }^{2}$ Research Institute for the Environment and Livelihoods, Charles Darwin University, Darwin, NT, Australia; ${ }^{35}$ th Medical Detachment, 168th \\ Multifunctional Medical Battalion, 65th Medical Brigade, Unit 15247, APO AP 96271-5247, USA
}

\begin{abstract}
Biting midges (Culicoides: Ceratopogonidae) were collected using New Jersey light traps at Yongsan US Army Garrison (USAG;urban), Seoul Metropolitan city and Camp Humphreys USAG (rural), Pyeongtaek, Gyeonggi-do (province), Republic of Korea , from May-October 2010-2013 and 2015-2017, to determine species composition and seasonal distribution patterns in urban and rural habitats. A total of 9,958 female (53.85\%) and 8,533 male (46.15\%) Culicoides comprising 16 species were collected. Overall, the most commonly collected species was Culicoides arakawae (74.3\%), followed by C. circumscriptus (16.2\%), C. kibunensis (2.5\%), C. nasuensis (2.2\%), C. clavipalpis (1.4\%), and C. pallidulus $(1.3 \%)$, while the remaining 10 species accounted for $<2.1 \%$ of all Culicoides spp. collected. The 2 predominant species collected were C. circumscriptus (47.4\%) and C. arakawae (33.4\%) at Yongsan, and C. arakawae (90.4\%) and C. circumscriptus (3.9\%) at Camp Humphreys. The seasonal abundance of these 2 species varied between years and between sites but on average peaked in August-September for $C$. arakawae and June-July for $C$. circumscriptus. Annual variations in abundance were observed for most species collected during this study. Unusually high proportions of male specimens were observed for most species at both sites which may be due to the use of the New Jersey trap.
\end{abstract}

Key words: Culicoides arakawae, Culicoides circumscriptus, biting midge, Korea

\section{INTRODUCTION}

Culicoides spp. Latreille (Diptera: Ceratopogonidae), or biting midges, are small (0.5-2.0 $\mathrm{mm}$ in length) bloodsucking insects that have broad distributions and impact on human and veterinary health as vectors of viruses, protozoans, and filarial worms throughout their range [1-5]. The first nationwide biting midge survey in the Republic of Korea (Korea) was reported in 1974 [6,7], while their relative seasonal abundance and host blood meal analysis collected from cattle and poultry farms in Gyeonggi-do were reported much later [8]. A recent summary of the history of Culicoides spp. and their seasonal prevalence for 9 cowsheds in the southern part of the Korea [9]

- Received 10 March 2021, revised 3 May 2021, accepted 31 May 2021.

*Corresponding author (terry.a.klein2.civ@mail.mil)

${ }^{\dagger}$ These authors contributed equally to this work.

"Present address: School of Medicine, Kangwon National University, Chuncheon 24341, Korea

(c) 2021, Korean Society for Parasitology and Tropical Medicine

This is an Open Access article distributed under the terms of the Creative Commons Attribution Non-Commercial License (https://creativecommons.org/licenses/by-nc/4.0) which permits unrestricted non-commercial use, distribution, and reproduction in any

medium, provided the original work is properly cited. and Jeju Island [10] were reported, along with 3 new species records (C. nasuensis Kitaoka, C. pallidulus Yu, and C. jacobsoni Macfie) [11], bringing the total number of Culicoides spp. reported in Korea to 31.

Vector-borne disease surveillance, including concurrent collections of mosquitoes, Culicoides spp., and other biting flies using New Jersey (NJ) light traps, was conducted by Force Health Protection \& Preventive Medicine (FHP\&PM), 65th Medical Brigade (MED BDE)/Medical Department ActivityKorea (MEDDAC-K). Collections of Culicoides spp. were conducted to determine their species composition and relative seasonal distributions for Yongsan US Army Garrison (USAG), Seoul Metropolitan city, an urban environment, and Camp Humphreys USAG, Anjeong-ri, Pyeongtaek, Gyeonggi-do a rural environment, (hereafter referred to as Yongsan and Camp Humphreys, respectively) in Korea.

\section{MATERIALS AND METHODS}

\author{
Survey areas \\ Yongsan, located in Seoul Metropolitan city, is approximate-
}


ly $30 \mathrm{~km}$ from the demilitarized zone (DMZ). Most of Yongsan and associated satellite communities are situated in urban environments surrounded by residential and commercial properties within the greater Seoul Metropolitan Area that occupies an area of approximately 640 acres of land just south of Namsan (South Mountain) and north of the Han River (Fig. 1). Small groves of deciduous and conifer trees are distributed among family housing and other operational/recreational structures. Potential breeding sites include open sewers, drainage systems, and small forest groves of mostly deciduous trees.

Camp Humphreys, bordered by Anjeong-ri, a small village near Pyeongtaek, Gyeonggi-do and surrounded by wetland (rice) and dry-land agriculture, was designated as a US military hub with a population of $>30,000$ military and civilian personnel and family members. Prior to 2008, Camp Humphreys consisted of an airstrip with associated structures for support, military housing and structures for military operations, a central stream, man-made water impoundments, and drainage ditches. In 2008, additional land was purchased for the expansion of Camp Humphreys. The purchased lands included lowlying hills with grasses/herbaceous vegetation, small groves of trees, major irrigation/drainage systems to reduce flooding, rice paddies, and limited dry-land farmland. During the construction phase, much of the land laid fallow with unmanaged grasses/herbaceous vegetation, except for areas immediately adjacent to Camp Humphreys that were under development for the construction of structures for military operations and

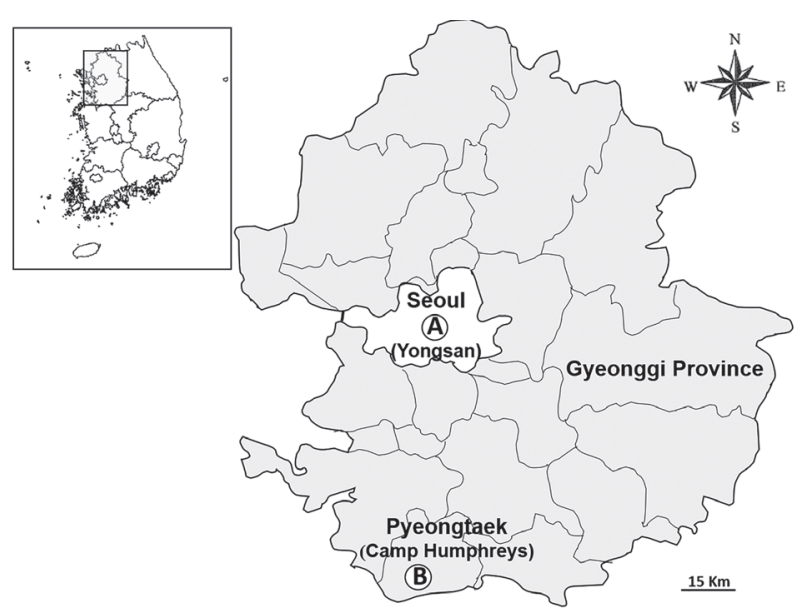

Fig. 1. Survey sites for Culicoides spp. collected using New Jersey light traps at Yongsan USAG in Seoul Metropolitan city and Camp Humphreys USAG, Pyeongtaek, Gyeonggi-do (province), Republic of Korea. (A) Yongsan USAG, (B) Camp Humphreys USAG. housing, roads, drainage systems, and recreation areas. Except for the expansion site, areas bordering structures and roadside ditches within Camp Humphreys were well maintained with small areas of unmanaged grasses/herbaceous vegetation and shrubs bordered ponds, streams, and drainage ditches that provides limited space, cover, and food for small (e.g., rodents), medium (e.g., raccoon dogs), and large (e.g., Korean Water deer) mammals. Large water birds were associated with large grassy areas, e.g., the airport, and multiple water impoundments. Construction included the gradual grading and filling of unmanaged fallow lands, and by 2016, much of the expansion site had been cleared of grasses/herbaceous vegetation and graded in preparation for land fill and construction of family housing, operational structures, and a central golf course with associated multiple water impoundments.

\section{Culicoides collection}

NJ light traps were employed 3 nights/week from 1 May-31 October as part of the mosquito-borne surveillance program that also included other biting flies (e.g., Culicoides spp.) at Yongsan and Camp Humphreys from 2010-2013 and 20152017. A total of 8 traps were operated by the Pest Control Section, Department of Public Works (DPW), Installation Management Command (IMCOM)-Korea, and collected specimens transported to the Entomology Section, FHP\&PM, MEDDAC-K/65th MED BDE. Culicoides spp. were separated from other biting flies and then transferred to $2 \mathrm{ml}$ cryovials containing 70\% ethanol (EtOH), according to trap location and date of collection, and later identified using dichotomous keys of Arnaud [12] and the descriptions and checklist of Bellis et al. [11]. Voucher specimens were submitted to the Research Institute for the Environment and Livelihoods, Charles Darwin University, Darwin, NT, Australia for future reference, genetic studies, and confirmation of dubious specimens.

\section{RESULTS}

A total of 18,491 Culicoides spp., comprised of 9,958 (53.85\%) females and 8,533 (46.15\%) males belonging to 16 species, were collected from 1 May through 31 October over 7 years from 2010-2013 and 2015-2017 at Yongsan and Camp Humphreys. Overall, the most commonly collected Culicoides species was Culicoides arakawae (74.3\%), followed by C. circumscriptus (16.2\%), C. kibunensis (2.5\%), C. nasuensis (2.2\%), C. clavipalpis (1.4\%), and C. pallidulus (1.3\%), while the remain- 
ing 10 species accounted for $<2.1 \%$ of all Culicoides spp. collected (Table 1). Culicoides circumscriptus (47.4\%) and C. arakawae (33.4\%) were the most commonly collected species at Yongsan, while C. arakawae (90.4\%) accounted for the majority of Culicoides spp. collected at Camp Humphreys, followed by C. circumscriptus (3.9\%) (Table 1). Collection records by year are attached for the 2 areas, Yongsan and Camp Hum- phreys, surveyed.

A total of 6,154 female Culicoides spp. belonging to 16 species were collected by NJ light traps at Camp Humphreys. Culicoides arakawae (84.9\%) females were the most frequently collected at Camp Humphreys, followed by C. circumscriptus (5.4\%), C. pallidulus (3.5\%), C. nasuensis (2.5\%), C. kibunensis $(1.5 \%)$, and C. nipponensis (1.2\%), while the remaining 10

Table 1. Total number of Culicoides females and males collected at Camp Humphreys USAG, Pyeongtaek, Gyeonggi-do, and Yongsan USAG, Seoul Metropolitan city, 2010-2013 and 2015-2017

\begin{tabular}{|c|c|c|c|c|c|c|c|c|c|}
\hline \multirow{2}{*}{ Culicoides spp. } & \multicolumn{2}{|c|}{ Camp Humphreys } & \multirow{2}{*}{$\%$} & \multicolumn{2}{|c|}{ Yongsan } & \multirow{2}{*}{$\%$} & \multicolumn{2}{|c|}{ Subtotal } & \multirow{2}{*}{ Total (\%) } \\
\hline & Female & Male & & Female & Male & & Female & Male & \\
\hline arakawae & 5,224 & 6,760 & 90.4 & 1,009 & 737 & 33.4 & 6,233 & 7,497 & $13,730(74.3)$ \\
\hline circumscriptus & 333 & 185 & 3.9 & 1,942 & 537 & 47.4 & 2,275 & 722 & 2,997 (16.2) \\
\hline clavipalpis & 6 & 0 & $<0.1$ & 226 & 29 & 4.9 & 232 & 29 & $261(1.4)$ \\
\hline dendrophilus & 1 & 0 & $<0.1$ & 10 & 4 & 0.3 & 11 & 4 & $15(<0.1)$ \\
\hline erairai & 2 & 0 & $<0.1$ & - & - & - & 2 & 0 & $2(<0.1)$ \\
\hline festivipennis & 1 & 0 & $<0.1$ & 22 & 5 & 0.5 & 23 & 5 & $28(0.2)$ \\
\hline homotomus & 1 & 0 & $<0.1$ & - & - & - & 1 & 0 & $1(<0.1)$ \\
\hline kibunensis & 93 & 11 & 0.8 & 312 & 47 & 6.9 & 405 & 58 & $463(2.5)$ \\
\hline longidens & 3 & 0 & $<0.1$ & - & - & - & 3 & 0 & $3(<0.1)$ \\
\hline morisitai & 18 & 35 & 0.4 & 3 & 0 & 0.1 & 21 & 35 & $56(0.3)$ \\
\hline nasuensis & 152 & 33 & 1.4 & 169 & 45 & 4.1 & 321 & 78 & 399 (2.2) \\
\hline nipponensis & 71 & 43 & 0.9 & 4 & 0 & 0.1 & 75 & 43 & $118(0.6)$ \\
\hline pallidulus & 214 & 22 & 1.8 & 2 & 0 & $<0.1$ & 216 & 22 & 238 (1.3) \\
\hline pictimargo & 1 & 0 & $<0.1$ & - & - & - & 1 & 0 & $1(<0.1)$ \\
\hline punctatus & 31 & 15 & 0.4 & 81 & 23 & 2 & 112 & 38 & $150(0.8)$ \\
\hline sinanoensis & - & - & - & 0 & 1 & $<0.1$ & 0 & 1 & $1(<0.1)$ \\
\hline tainanus & 3 & 0 & $<0.1$ & 24 & 1 & 0.5 & 27 & 1 & $28(0.2)$ \\
\hline Total & 6,154 & 7,104 & & 3,804 & 1,429 & & 9,958 & 8,533 & 18,491 \\
\hline$\%$ & 46.4 & 53.6 & 100 & 72.7 & 27.3 & 100 & 53.85 & 46.15 & 100 \\
\hline
\end{tabular}

Table 2. Distribution of 16 female Culicoides spp. by month at Camp Humphreys USAG, Pyeongtaek, Gyeonggi-do, 2010-2013 and 2015-2017

\begin{tabular}{lrrrrrrrrrrrrrr}
\hline Culicoides spp. & May & $\%$ & June & $\%$ & July & $\%$ & August & $\%$ & $\begin{array}{c}\text { Sep- } \\
\text { tember }\end{array}$ & October & $\%$ & Total & $\%$ \\
\hline arakawae & 67 & 69.8 & 472 & 53.2 & 475 & 77.6 & 1,765 & 89.2 & 2,187 & 94.6 & 258 & 96.6 & 5,224 & 84.9 \\
circumscriptus & 5 & 5.2 & 152 & 17.1 & 65 & 10.6 & 44 & 2.2 & 62 & 2.7 & 5 & 1.9 & 333 & 5.4 \\
clavipalpis & 0 & 0 & 1 & 0.1 & 5 & 0.8 & 0 & 0 & 0 & 0 & 0 & 0 & 6 & 0.1 \\
dendrophilus & 0 & 0 & 0 & 0 & 1 & 0.2 & 0 & 0 & 0 & 0 & 0 & 0 & 1 & $<0.1$ \\
erairai & 0 & 0 & 2 & 0.2 & 0 & 0 & 0 & 0 & 0 & 0 & 0 & 0 & 2 & $<0.1$ \\
festivipennis & 0 & 0 & 0 & 0 & 1 & 0.2 & 0 & 0 & 0 & 0 & 0 & 0 & 1 & $<0.1$ \\
homotomus & 0 & 0 & 1 & 0.1 & 0 & 0 & 0 & 0 & 0 & 0 & 0 & 0 & 1 & $<0.1$ \\
kibunensis & 0 & 0 & 40 & 4.5 & 8 & 1.3 & 35 & 1.8 & 8 & 0.3 & 2 & 0.7 & 93 & 1.5 \\
longidens & 0 & 0 & 3 & 0.3 & 0 & 0 & 0 & 0 & 0 & 0 & 0 & 0 & 3 & $<0.1$ \\
morisitai & 0 & 0 & 1 & 0.1 & 0 & 0 & 7 & 0.4 & 10 & 0.4 & 0 & 0 & 18 & 0.3 \\
nasuensis & 0 & 0 & 110 & 12.4 & 10 & 1.6 & 28 & 1.4 & 4 & 0.2 & 0 & 0 & 152 & 2.5 \\
nipponensis & 9 & 9.4 & 4 & 0.5 & 4 & 0.6 & 48 & 2.4 & 6 & 0.3 & 0 & 0 & 71 & 1.2 \\
pallidulus & 9 & 9.4 & 95 & 10.7 & 34 & 5.6 & 39 & 2 & 35 & 1.5 & 2 & 0.7 & 214 & 3.5 \\
pictimargo & 0 & 0 & 1 & 0.1 & 0 & 0 & 0 & 0 & 0 & 0 & 0 & 0 & 1 & $<0.1$ \\
punctatus & 6 & 6.2 & 6 & 0.7 & 8 & 1.3 & 10 & 0.5 & 1 & $<0.1$ & 0 & 0 & 31 & 0.5 \\
tainanus & 0 & 0 & 0 & 0 & 1 & 0.2 & 2 & 0.1 & 0 & 0 & 0 & 0 & 3 & $<0.1$ \\
Total & 96 & & 888 & & 612 & & 1,978 & & 2,313 & & 267 & 6,154 & 100.0 \\
\hline
\end{tabular}


Table 3. Distribution of 12 female Culicoides spp. by month at Yongsan USAG, Seoul Metropolitan city, 2010-2013 and 2015-2017

\begin{tabular}{|c|c|c|c|c|c|c|c|c|c|c|c|c|c|c|}
\hline Culicoides spp. & May & $\%$ & June & $\%$ & July & $\%$ & August & $\%$ & $\begin{array}{l}\text { Sep- } \\
\text { tember }\end{array}$ & $\%$ & October & $\%$ & Total & $\%$ \\
\hline arakawae & 26 & 7 & 101 & 9.1 & 89 & 11.7 & 371 & 43 & 286 & 58.5 & 136 & 66.3 & 1,009 & 26.5 \\
\hline circumscriptus & 165 & 44.2 & 878 & 79 & 520 & 68.2 & 231 & 26.8 & 98 & 20.1 & 50 & 24.4 & 1,942 & 51.1 \\
\hline clavipalpis & 3 & 0.8 & 39 & 3.5 & 50 & 6.5 & 109 & 12.6 & 24 & 4.9 & 1 & 0.5 & 226 & 5.9 \\
\hline dendrophilus & 2 & 0.5 & 4 & 0.4 & 2 & 0.3 & 0 & 0 & 2 & 0.4 & 0 & 0 & 10 & 0.3 \\
\hline festivipennis & 1 & 0.3 & 1 & 0.1 & 2 & 0.3 & 8 & 0.9 & 10 & 2 & 0 & 0 & 22 & 0.6 \\
\hline kibunensis & 144 & 38.6 & 25 & 2.2 & 42 & 5.5 & 59 & 6.9 & 36 & 7.4 & 6 & 2.9 & 312 & 8.2 \\
\hline morisitai & 0 & 0 & 0 & 0 & 1 & 0.1 & 1 & 0.1 & 1 & 0.2 & 0 & 0 & 3 & 0.1 \\
\hline nasuensis & 20 & 5.4 & 47 & 4.2 & 29 & 3.8 & 54 & 6.3 & 17 & 3.5 & 2 & 1 & 169 & 4.4 \\
\hline nipponensis & 0 & 0 & 2 & 0.2 & 0 & 0 & 0 & 0 & 2 & 0.4 & 0 & 0 & 4 & 0.1 \\
\hline pallidulus & 0 & 0 & 1 & 0.1 & 0 & 0 & 0 & 0 & 1 & 0.2 & 0 & 0 & 2 & 0.1 \\
\hline punctatus & 11 & 2.9 & 11 & 1 & 20 & 2.6 & 21 & 2.4 & 10 & 2 & 8 & 3.9 & 81 & 2.1 \\
\hline tainanus & 1 & 0.3 & 2 & 0.2 & 8 & 1 & 9 & 1 & 2 & 0.4 & 2 & 1 & 24 & 0.6 \\
\hline Total & 373 & & 1,111 & & 763 & & 863 & & 489 & & 205 & & 3,804 & 100.0 \\
\hline
\end{tabular}

A

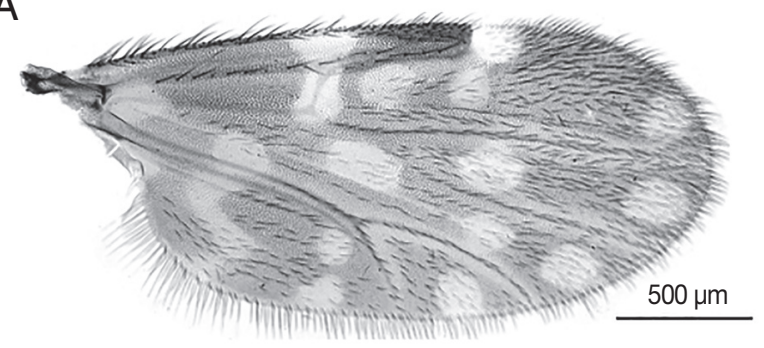

B

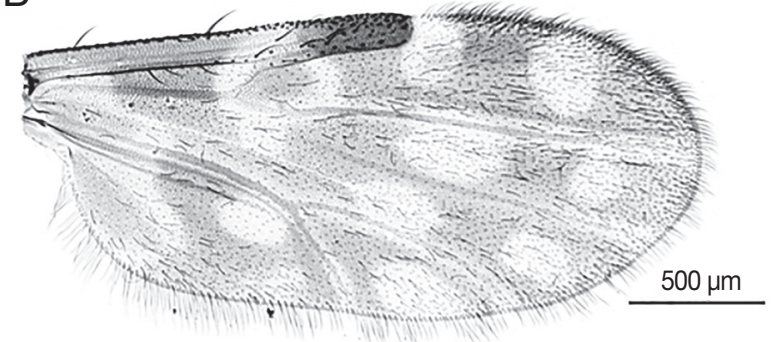

Fig. 2. Wing venation of 2 predominant species, Culicoides arakawae (A) and Culicoides circumscriptus (B) collected using New Jersey light traps at Yongsan USAG and Camp Humphreys USAG, Republic of Korea.

species accounted for $1.0 \%$ of all Culicoides spp. collected (Table 2). In contrast to the rural area at Camp Humphreys, a total of 12 female Culicoides spp. (and one male of another species) were collected from an urban area at Yongsan. At Yongsan, C. circumscriptus (51.1\%) females were the most frequently collected, followed by C. arakawae (26.5\%), C. kibunensis (8.2\%), C. clavipalpis (5.9\%), C. nasuensis (4.4\%), and C. punctatus $(2.1 \%)$, while the remaining 6 species accounted for $1.8 \%$ of all Culicoides females collected (Table 3). The proportion of males specimens collected varied between species and areas collected (Table 1).

The annual trap index (TI=number of females collected/ trap night) of C. arakawae collected at Camp Humphreys did not vary significantly, except for a sharp increase that was observed in August of 2013 and 2015 that persisted through September until the population decreased in October of both years. A similar trend was observed at Yongsan, but the sharp increase was observed only from August through September 2013, with numbers continuing to increase until October when trapping ceased (Fig. 3A, C). Annual variation in abundance of $C$. circumscriptus females was observed in June-July at Camp Humphreys, except during 2015 when a sharp increase was observed in September (Fig. 3). A similar trend was observed at Yongsan, but the sharp increase was observed in both June 2016 and June-July 2015. Low numbers were collected at both areas and the variation observed was likely due to minor changes in the numbers collected (Fig. 3B, D).

Comparing the 7-year TI of C. arakawae and C. circumscriptus, the dominant species of both urban and rural areas, $C$. circumscriptus peaked in June at Yongsan, an urban area, while $C$. arakawae peaked in September at Camp Humphreys, which is adjacent to farmlands (Figs. 2, 4). At Yongsan, seasonal population trends for the most frequently collected species, $C$. circumscriptus, differed from C. arakawae, with low numbers collected during May $(\mathrm{TI}=0.30)$, followed by sharp increases in TIs during June-July ( $\mathrm{TI}=0.85-1.36$, respectively), before sharply decreasing to low numbers from August-October ( $\mathrm{TI}=0.2-0.37$, respectively). At Camp Humphreys, low num- 

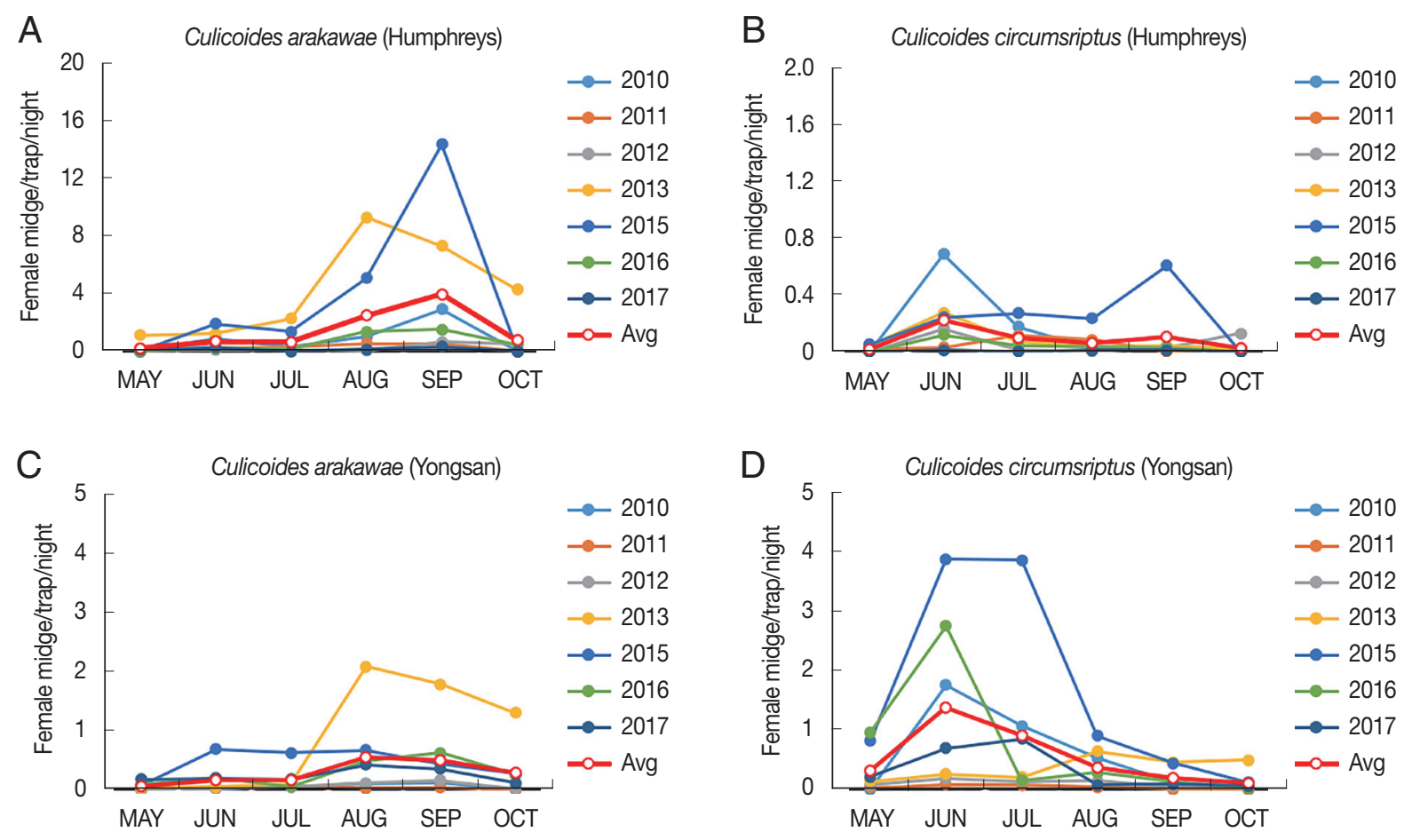

Fig. 3. Annual variation of females of 2 predominant species, Culicoides arakawae and Culicoides circumscriptus collected using New Jersey light traps at Yongsan USAG and Camp Humphreys USAG, Republic of Korea.

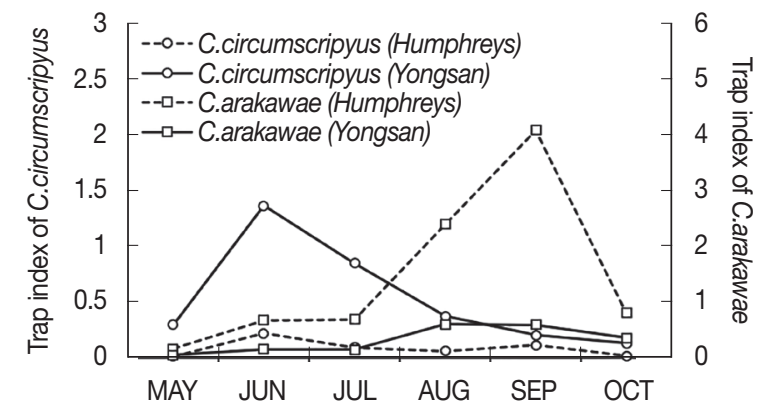

Fig. 4. Overall seasonal prevalence of 2 predominant species of female biting midges based on the trap index (number of female Culicoides spp./trap/night) of Culicoides arakawae (square) and Culicoides circumscriptus (circle), collected using New Jersey light traps at 2 collection areas at Yongsan USAG, and Camp Humphreys USAG, Republic of Korea, 2010-2013 and 20152017.

bers of $C$. arakawae, the most frequently collected species, were collected during May-July ( $\mathrm{TI}=0.07-0.69$, respectively), followed by sharp increases in TIs during August-September $(\mathrm{TI}=2.4-4.08$ respectively), followed by a sharp decrease in October (Fig. 4).

\section{DISCUSSION}

Culicoides or biting midges are both nuisance biters (e.g. hypersensitivity to bites) and vectors of pathogens of medical (e.g., Mansonella spp. filarial worms) and veterinary importance. Bluetongue virus was first isolated from a cow in Korea, with infections impacting the economy of the animal industry in Korea [4,5,13-16].

Although the abundance of individual species varied between the urban and rural sites, similar numbers of species were collected at both Yongsan (12) and Camp Humphreys (16). In a previous report, C. punctatus and C. nipponensis were the most frequently collected species at a cowshed [8,9], suggesting that these species are attracted to cattle, and reflects their feeding preferences $[8,17]$. However, in this survey, while C. punctatus and C. nipponensis were collected in relatively low numbers at Yongsan (2.1\% of the total species collected) and Camp Humphreys $(0.5 \%)$, there was even a much lower proportion of females. The low numbers of these species is likely due to the absence of cattle from these locations.

The predominance and wide distribution of $C$. arakawae and C. circumscriptus reported by Cho and Chong [7] using NJ light traps was similar to our results. Although $C$. arakawae ap- 
pears to have a preference for feeding on birds [18], it also readily feeds on cattle $[8,17]$. The greater abundance of $C$. arakawae at Camp Humphreys is likely due to the higher prevalence of larval habitat, e.g., rice paddies [19], in this area compared to Yongsan. The reason for greater numbers of $C$. circumscriptus at Yongsan than at Camp Humphreys is less clear. Although this species has been reared from saline mud [20-22], it is not confined to this habitat and Braverman et al. [23] reared this species from a wide range of muddy habitats, particularly those rich in organic matter and low in oxygen. Presumably, such habitats as open sewers and ditches are more common at Yongsan than at Camp Humphreys

The relatively high proportion of males collected in this study was unexpected. Cho and Chong [7] reported similarly high proportions of males in NJ light traps compared to results reported for the same range of species in Korea using black light traps [9] and for species collected elsewhere using light traps, e.g., India [24], Europe [25], and Turkey [26]. This potential difference in attractiveness of $\mathrm{NJ}$ light traps for male Culicoides requires further exploration to elicit factors causing this difference.

Culicoides arakawae has been associated with the transmission of important livestock pathogens, e. g., African horse sickness, bluetongue, Fukuoka, Aino, and Ibaraki viruses [3,5,27, 28], and Leucocytozoon caulleryi (a protozoan in southeast Asia and Japan), and as potential vectors of other viruses and filarial worms (e.g., Mansonella spp.) of medical importance, in addition to their painful bites that may elicit a severe reaction in both humans and animals [29-32].

The abnormal seasonal abundance pattern observed for several species illustrates the importance of long-term studies to provide a reasonable understanding of seasonality of Culicoides populations. For example, had this study only been conducted in 2013 at Yongsan, a false impression of the seasonality of $C$. arakawae with a strong peak in October would have emerged. Differences in species diversity are also vulnerable to annual variation.

Additionally, seasonal abundance data based on low numbers of specimens, for example our data for C. circumscriptus at Camp Humphreys, are very vulnerable to individual collections containing just a few specimens, and such data needs to be analyzed with caution. Studies on the geographical and seasonal distributions, host attraction (e.g., placement of traps near human habitation and poultry, cattle, and swine farms), temporal biting activity, pathogen infection rates, and their role as potential vectors of zoonotic pathogens that impact human and animal health are warranted. Although limited, the data presented herein provides a better understanding of the biology, ecology, and environmental parameters that affect relative population abundance of Culicoides spp. that can be used to predict potential human and animal health risks for the development and implementation of mitigation strategies. Alternate trap models, e.g., green LED-CDC light traps and Mosquito Magnet traps, may capture additional species or different proportions of the various species.

\section{ACKNOWLEDGMENTS}

We thank the commanders and soldiers of the 5th Medical Detachment, 168th Multifunctional Medical Battalion, 65th Medical Brigade, for their assistance in conducting vectorborne disease surveillance. We thank Mr. Ho-Gil An, Yongsan USAG, Seoul, and Mr, Pyong-Chol Cho, Camp Humphreys USAG, Foreman of the Pest Control Section, DPW, IMCOMKorea, for their assistance in conducting surveillance of mosquitoes and other biting flies. Funding for portions of the surveillance of Culicoides spp. was provided by the Armed Forces Health Surveillance Division-Global Emerging Infections Surveillance Section (AFHSB-GEIS), Silver Spring, MD, USA (ProMIS ID \#0025_17_ME); and the 65th Medical Brigade, Seoul, Korea. The opinions expressed herein are those of the authors and are not to be construed as official or reflecting the views of the US Departments of the Army or Defense. MSK, HCK, STC and TAK are U.S. Government employees, this work was prepared as part of their official duties. Title 17 U.S.C. $\$ 105$ provides that 'Copyright protection under this title is not available for any work of the United States Government.' Title 17 U.S.C. $\$ 101$ defines a U.S. Government work as a work prepared by a military service member or employee of the U.S. Government as part of that person's official duties.

\section{CONFLICT OF INTEREST}

We have no conflict of interest related with this work.

\section{REFERENCES}

1. Linley JR, Hoch AL, Pinheiro FP. Biting midges (Diptera: Ceratopogonidae) and human health. J Med Entomol 1983; 20: 347364. https://doi.org/10.1093/jmedent/20.4.347 
2. Meiswinkel R, Labuschagne K, Baylis M, Mellor PS. Multiple vectors and their differing ecologies: observations on two bluetongue and African horse sickness vector Culicoides species in South Africa. Vet Ital 2004; 40: 296-302. https://pubmed.ncbi. nlm.nih.gov/20419682/

3. Yanase T, Kato T, Kubo T, Yoshida K, Ohashi S, Yamakawa M, Miura Y, Tsuda T. Isolation of bovine arboviruses from Culicoides biting midges (Diptera: Ceratopogonidae) in Southern Japan: 19852002. J Med Entomol 2005; 42: 63-67. https://doi.org/10.1093/ jmedent/42.1.63

4. Shin YK, Oem JK, Yoon S, Hyun BH, Cho IS, Yoon SS, Song JY. Monitoring of five bovine arboviral diseases transmitted by arthropod vectors in Korea. J Bacteriol Virol 2009; 39: 353-362. https://doi.org/10.4167/jbv.2009.39.4.353

5. Yang, D, Yang MS, Rhim H, Han JI, Oem JK, Kim YH, Lee KK, Lim CW, Kim B. Analysis of five arboviruses and Culicoides distribution on cattle farms in Jeollabuk-do, Korea. Korean J Parasitol 2018;56: 477-485. https://doi.org/10.3347/kjp.2018.56.5.477

6. Cho HC, Chong CS, Yu HS. Notes on Biting Midges of the Culicoides from South Korea. Rep. Yongsan, Korea. 5th Preventive Medicine Unit, 8th US Army. 1972, pp 1-64.

7. Cho HC, Chong CS. Notes on biting midges of the Culicoides from South Korea: with special reference to unrecorded species and distribution. Korean J Parasitol 1974; 12: 45-75. https://doi. org/10.3347/kjp.1974.12.1.45

8. Kang CH, Yu HS. Seasonal abundance and host blood meal sources of the genus Culicoides (Diptera: Ceratopogonidae) from cattle and poultry farms in Kyonggi Province, Korea. Korean J Entomol 1991; 21: 29-36. https://agris.fao.org/agris-search/search. do? recordID =KR9235364

9. Kim HC, Bellis GA, Kim MS, Chong ST, Lee DK, Park JY, Yeh JY, Klein TA. Seasonal abundance of biting midges, Culicoides spp. (Diptera: Ceratopogonidae), collected at cowsheds in the southern part of the Republic of Korea. Korean J Parasitol 2012; 50: 127-131. https://doi.org/10.3347/kjp.2012.50.2.127

10. Kim HC, Bellis GA, Kim MS, Klein TA, Gopurenko D., Cai DC, Seo HJ, Cho IS, Park JY. Species diversity and seasonal distribution of Culicoides spp. (Diptera: Ceratopogonidae) in Jeju-do, Republic of Korea. Korean J Parasitol 2015; 53: 501-506. https:// doi.org/10.3347/kjp.2015.53.4.501

11. Bellis GA, Kim HC, Kim MS, Klein TA, Lee DK, Gopurenko D. Three species of Culicoides Latreille (Diptera: Ceratopogonidae) newly recorded from the Republic of Korea. Zootaxa 2013; 3718: 171-182. https://doi.org/10.11646/zootaxa.3718.2.5

12. Arnaud P. The heleid genus Culicoides in Japan, Korea and Ryukyu Island (Insecta: Diptera). Microentomol 1956; 21: 84207. https://ci.nii.ac.jp/naid/10013303803/

13. Anderson GS, Belton P, Kleider N. Hypersensitivity of horses in British Columbia to extracts of native and exotic species of Culicoides (Diptera: Ceratopogonidae). J Med Entomol 1993; 30: 657-663. https://doi.org/10.1093/jmedent/30.4.657

14. Oem JK, Chung JY, Kwon MS, Kim TK, Lee TU, Bae YC. Abundance of biting midge species (Diptera: Ceratopogonidae, Culi- coides spp.) on cattle farms in Korea. J Vet Sci 2013; 14: 91-94. https://doi.org/10.4142/jvs.2013.14.1.91

15. Seo HJ, Park JY, Cho YS, Cho IS, Yeh JY. First report of bluetongue virus isolation in the Republic of Korea and analysis of the complete coding sequence of the segment 2 gene. Virus Genes 2015; 50: 156-159. https://doi.org/10.1007/s11262-014$1140-2$

16. Lee, HR, Koo BS, Kim JT, Kim HC, Kim MS, Klein TA, Shin MS, Lee SH, Jeon EO, Min KC, Lee SB, Bae YJ, Mo IP. Molecular epidemiology of avian poxvirus in the Oriental turtle dove (Streptopelia orientalis) and the biting midge (Culicoides arakawae) in the Republic of Korea. J Wildl Dis 2017; 53: 749-760. https://doi. org/10.7589/2016-10-230

17. Lee YJ. Ecological studies in the genus Culicoides in Korea. MS Thesis. Incheon University; 1993.

18. Kitaoka S, Cheah TS. Seasonal incidence and feeding preference of Culicoides species caught in chicken houses and cattle sheds at Ipoh in Peninsular Malaysia (Diptera: Ceratopogonidae). Malaysian Vet J 1983; 7: 245-253. https://agris.fao.org/agris-search/ search.do?recordID=XB8405636

19. Tokunaga M, Takiyama K, Tanaka M, Yoshikawa H. Early stages and breeding place of Culicoides arakawae (Diptera: Ceratopogonidae). Rep Kyoto Univ Agric 1961; 13: 53-59. https://core.ac.uk/ reader/235429550

20. Tokunaga M. Sandflies (Ceratopogonidae, Diptera) from Japan. Tenthredo 1937; 1: 233-338.

21. Kettle DS, Lawson JWH. The early stages of British biting midges Culicoides Latreille (Diptera: Ceratopogonidae) and allied genera. Bull Entomol Res 1952; 43: 421-467. https://doi.org/10.1017/ S000748530002945X

22. Becker P. Observations on Culicoides circumscriptus Kieffer (Diptera, Ceratopogonidae=Heleidae). Ph. D. Dissertation. Glasgow, Scotland. Glasgow University; 1956, pp 182. http://theses.gla. ac.uk/73566/

23. Braverman Y, Galun R, Ziv M. Breeding sites of some Culicoides species (Diptera, Ceratopogonidae) in Israel. Mosq News 1974; 34: 303-308.

24. Harsha R, Mazumdar A. Prevalence and age grading of Culicoides spp. (Diptera: Ceratopogonidae), potent vectors of bluetongue disease of farm animals in Bikaner, Rajasthan. Proc Zool Soc 2015; 68: 212-216. https://doi.org/10.1007/s12595-014-0110-y

25. Möhlmann TWR, Wennergren U, Tälle M, Favia G, Damiani C, Bracchetti L, Takken W, Koenraadt CJM. Community analysis of the abundance and diversity of biting midge species (Diptera: Ceratopogonidae) in three European countries at different latitudes. Parasit Vectors 2018; 11: 217. https://doi.org/10.1186/ s13071-018-2792-x

26. Deniz A, Öncel T, Patakakis MJ. Species composition of Culicoides Latreille, 1809 (Diptera: Ceratopogonidae) in Thrace region of Turkey. Kafkas Univ Vet Fak Derg 2010; 16: 1057-1060.

27. Kaneko N, Inaba Y, Akashi H, Miura Y, Shorthose J, Kurashige K. Isolation of a new bovine ephemeral fever group virus. Aust Vet J 1985; 62: 388-389. https://doi.org/10.1111/j.1751-0813.1985. 
tb14220.x

28. Kaneko N, Inaba Y, Akashi H, Miura Y, Shorthose J, Kurashige K. Isolation of a new bovine ephemeral fever group virus. Aust Vet J 1986; 63: 29-29. https://doi.org/10.1111/j.1751-0813.1986.tb02870.x

29. Takahasi H. Notes on some species of the Genus Culicoides from Manchoukuo with description of a new species (Ceratopogonidae, Diptera). Insecta Mats 1941; 15: 80-85. http://hdl.handle. net/2115/9465

30. Barnett HC, Toshioka S. The Bloodsucking Insects, Mites and
Ticks of Korea and Their Relation to Disease Transmission. San Francisco, USA. 406th Medical General Lab. 1951, pp 1-25.

31. Braverman Y, Galun R. The occurrence of Culicoides in Israel with reference to the incidence of bluetongue. Refuah Veterinarith 1973; 30: 121-127.

32. Becker P. Observations on the feeding and mating of Culicoides circumscriptus Kieffer (Diptera: Ceratopogonidae). Physiol Entomol 2009; 35: 6-11. https://doi.org/10.1111/j.1365-3032.1960. tb00655.x 